Article

\title{
Antimicrobial and Antibiofilm Activities of Citrus Water-Extracts Obtained by Microwave-Assisted and Conventional Methods
}

\author{
Leonardo Caputo ${ }^{1}$, Laura Quintieri ${ }^{1}$, Maria Maddalena Cavalluzzi ${ }^{2}$, Giovanni Lentini ${ }^{2}$ (D) \\ and Solomon Habtemariam ${ }^{3, *}$ \\ 1 Institute of Sciences of Food Production (CNR-ISPA) National Council of Research, Via G. Amendola, \\ 122/O, 70126 Bari, Italy; leonardo.caputo@ispa.cnr.it (L.C.); laura.quintieri@ispa.cnr.it (L.Q.) \\ 2 Department of Pharmacy-Drug Sciences, University of Studies of Bari Aldo Moro, Via E. Orabona, 4, \\ 70126 Bari, Italy; mariamaddalena.cavalluzzi@uniba.it (M.M.C.); giovanni.lentini@uniba.it (G.L.) \\ 3 Pharmacognosy Research Laboratories \& Herbal Analysis Services, University of Greenwich, \\ Central Avenue, Chatham-Maritime, Kent ME4 4TB, UK \\ * Correspondence: s.habtemariam@herbalanalysis.co.uk; Tel.: +44-20-8331-8302/8424
}

Received: 31 May 2018; Accepted: 15 June 2018; Published: 17 June 2018

\begin{abstract}
Citrus pomace is a huge agro-food industrial waste mostly composed of peels and traditionally used as compost or animal feed. Owing to its high content of compounds beneficial to humans (e.g., flavonoids, phenol-like acids, and terpenoids), citrus waste is increasingly used to produce valuable supplements, fragrance, or antimicrobials. However, such processes require sustainable and efficient extraction strategies by solvent-free techniques for environmentally-friendly good practices. In this work, we evaluated the antimicrobial and antibiofilm activity of water extracts of three citrus peels (orange, lemon, and citron) against ten different sanitary relevant bacteria. Both conventional extraction methods using hot water (HWE) and microwave-assisted extraction (MAE) were used. Even though no extract fully inhibited the growth of the target bacteria, these latter (mostly pseudomonads) showed a significant reduction in biofilm biomass. The most active extracts were obtained from orange and lemon peel by using MAE at $100{ }^{\circ} \mathrm{C}$ for $8 \mathrm{~min}$. These results showed that citrus peel water infusions by MAE may reduce biofilm formation possibly enhancing the susceptibility of sanitary-related bacteria to disinfection procedures.
\end{abstract}

Keywords: citron; lemon; orange; solvent-free extraction; pseudomonads; staphylococci; Escherichia

\section{Introduction}

Humans contribute to the microbiome biodiversity by being the main reservoirs and carriers of various microorganisms. As some of these microorganisms may occasionally cause severe infections [1,2], various prophylaxis measures have to be implemented to reduce the microbial load. Of particular significance is an approach to reduce the microbial burden in confined environments such as schools, hospitals, and even general medical devices [3-5]. Among the main microorganisms with hygienic-sanitary interest are Staphylococcus and Pseudomonas which can cause several human diseases. They also associated with an increased resistance to a number of antibiotics. Staphylococci are naturally present as saprophytes on the skin and mucous membranes of mammals and generally only a few species are pathogenic, causing serious infections to humans [6]. The pathogenicity of saprophytic bacteria is due to alteration of the microbiome, as in the case of Staphylococcus epidermidis and S. saprophyticus which may cause atopic dermatitis [7] and urinary tract infections [8], respectively. Unlike staphylococci, pseudomonads can easily adapt to substrates with poor nutrients (i.e., cosmetics) or grow on materials (i.e., medical devices) in contact with human skin or mucosae [1]. 
Recently, in addition to the most feared pathogen, Pseudomonas aeruginosa, some pseudomonads species (e.g., P. fluorescens) which are generally considered non-pathogenic are understood to be opportunistic bacteria as they trigger pathogenesis in debilitated and immunocompromised patients [9].

Most of these pathogenic bacteria form biofilms during their growth through distinct cyclic phases of attachment and adhesion to the substrate, proliferation and maturation, and finally a dispersion phase involving detachment of cells that initiate a new biofilm [10]. Biofilm formation is the cause of increased morbidity and mortality in hospital infections. As it is also closely linked to infection persistence and resistance to common antimicrobial agents, its relevance to disinfection strategies is gaining significance [11,12]. Therefore, there is a growing interest in research directed to the identification of new compounds or innovative control strategies against biofilm formation. Antimicrobial compounds extracted from cheap natural materials (i.e., agro-food industrial waste) through sustainable methodologies have been increasingly considered as new sources to meet this need. Among the known advantages of this strategy is the possibility to hinder microbial growth without the risk of yielding drug-resistant strains [13]. The sustainable utilization of citrus fruit processing waste (mostly peels), which at worldwide level may be estimated in about $14 \times 10^{6}$ tons per year [14], could be a promising strategy in bacterial biofilm control. In fact, citrus waste disposal is not only burdensome for manufacturing factories but constitutes an environmental threat because of the high level of fermentable sugars in citrus pomace [14].

Moreover, the recovery of high value products from citrus waste may increase the economic yield of the citrus processing industries. Recently, Citrus spp. extracts showed several biological activities [15-17] including antimicrobial effects against pathogenic bacteria and fungi [18]. However, antimicrobial compounds have been recovered by extraction with organic solvents or as essential oils. To avoid the use of organic solvents, the processing of citrus waste for obtaining enriched extracts therefore targeted the water-soluble antimicrobial substances. Innovative "green" strategies (water extraction, supercritical fluids, microwave assisted extraction (MAE)) have, however, been shown to overcome such limitations (i.e., organic solvent utilisation) and provide higher yields and energy savings [19]. Even though solvent-free MAE has been investigated to extract antimicrobial plant compounds [20], very limited studies have been carried out on citrus extracts [13,21]. Furthermore, the extraction of citrus peels by using water or saline solution allowed antimicrobial molecules against oral bacteria to be obtained, such as the glycoside phlorin (3,5-dihydroxyphenyl $\beta$-D-glucopyranoside) $[22,23]$ and other flavonoids. To increase the antimicrobial activity of water extracts of citrus peels, the time and temperature of the extraction process should also be carefully considered. On the basis of preliminary studies on antibiofilm activity of some citrus extracts [24,25], further detailed studies must be considered to implement a successful strategy that counteract microbial persistence. On this basis, the present study assessed aqueous extracts obtained from peels of highly widespread citrus fruits (lemon and orange) and citron (generally used in drink and candied fruit manufacturing). The extracts obtained through both prolonged infusion in warm water and MAE at a high temperature were assayed for their antibacterial and antibiofilm activities against saprophytic staphylococci and pseudomonads.

\section{Experimental Section}

\subsection{Plant Material}

Citrons (Citrus medica [L].cv. Diamante) were kindly provided by "Consorzio del Cedro di Calabria" Association (Santa Maria del Cedro, Italy); sweet oranges (C. sinensis [L.] Osbeck cv. Washington Navel) were donated by the organic farm Gabriella Caruso s.r.l. (Corigliano Calabro, Italy); and lemons (C. lemon [L.] Burm cv. Sfusato di Amalfi) were collected in a personal orchard (Caputo L., Cellamare, Italy). After washing twice with distilled water, fruits $(c a .2 \mathrm{~kg}$ ) were dried at room temperature for $1 \mathrm{~h}$ and peeled. The recovered peels of each fruit sample were immediately cooled on ice and subsequently freeze-dried. The lyophilized peel samples were finely grounded with Osterizer 
12-speed blender (Osteriz, Boca Raton, FL, USA) to obtain a fine powder and stored at $-20^{\circ} \mathrm{C}$ in air tight bags for further analyses.

\subsection{Hot Water Extraction (HWE)}

HWE was performed as reported by Louche et al. [22] with minor modification. Briefly, $2 \mathrm{~g}$ of each lyophilized peel was accurately $( \pm 0.01 \mathrm{~g})$ weighed and transferred into $50 \mathrm{~mL} \mathrm{Falcon}^{\mathrm{TM}}$ tubes with screw caps containing $24 \mathrm{~mL}$ of pre-heated MilliQ water (Merck Millipore, Darmstadt, Germany). The extraction mixture was refluxed at $50{ }^{\circ} \mathrm{C}$ for $24 \mathrm{~h}$ in a Thermomixer R (Eppendorf, Westbury, NY, USA) shaking at $400 \mathrm{rpm}$. At the end of extraction, samples were centrifuged at 13,000 rpm for $15 \mathrm{~min}$ followed by each supernatant sterile-filtered and freeze-dried.

\subsection{Microwave-Assisted Extraction (MAE)}

Peel powder $(1 \mathrm{~g})$ of each citrus peel was dissolved in $12 \mathrm{~mL}$ of MilliQ water and extracted using CEM Discover Microwave (CEM Corporation, Cologno al Serio, Italy) operating at $10 \mathrm{~W}$ and under the following three experimental conditions: $80{ }^{\circ} \mathrm{C}$ for $20 \mathrm{~min}$ (MAE1); $100{ }^{\circ} \mathrm{C}$ for 8 min (MAE2); or $100{ }^{\circ} \mathrm{C}$ for $20 \mathrm{~min}$ (MAE3). For each sample was extracted in duplicate and pooled to obtain a total volume of $24 \mathrm{~mL}$. As with the HWE, samples were centrifuged at 13,000 rpm for $15 \mathrm{~min}$, supernatant sterile-filtered and freeze-dried. All extractions were performed in triplicate.

\subsection{Yield (\%) of Peel Extracts and Preparation for Bioassay}

The percent yield of different citrus peel extracts from the HWE and MAE was assessed from comparative freeze-dried extract obtained (in triplicate) with respect to the respective freeze-dried peel as a starting material. The lyophilized extracts were dissolved in one tenth-volume with MilliQ water and centrifuged again. The supernatants were sterile-filtered through $0.22 \mu \mathrm{m}$ cellulose acetate syringe filters (Whatman Inc., Dassel, Germany) and stored at $-20^{\circ} \mathrm{C}$ until their use.

\subsection{Bacteria and Culture Conditions}

Target strains used in antimicrobial and antibiofilm assays were obtained from the ISPA-CNR microbial collection stored at $-80{ }^{\circ} \mathrm{C}$. Before their use, all strains were freshly cultured overnight under aerobic conditions as shown in Table 1. Growth media were purchased from Thermo Fisher Scientific (Rodano, Italy).

Table 1. Target strains, growth media and culture conditions.

\begin{tabular}{cc}
\hline Target Strain & Growth Conditions \\
\hline Staphylococcus epidermidis UR63 & \\
Staphylococcus saprophyticus UR18 & Tryptic Soy Broth (TSB), $37^{\circ} \mathrm{C}, 130 \mathrm{rpm}$ \\
Staphylococcus caprae DSM 20608 & \\
Staphylococcus xylosus DSM20266T & \\
\hline Pseudomonas fluorescens NCPPB1964 & \\
Pseudomonas fluorescens ITEM 17298 & \\
Pseudomonas fluorescens ITEM 17299 & Luria Bertani (LB), $30{ }^{\circ} \mathrm{C}, 130 \mathrm{rpm}$ \\
Pseudomonas fluorescens ITEM 84094 & \\
Pseudomonas putida ITEM 17297 & \\
\hline Escherichia coli K12 & Luria Bertani (LB), $37^{\circ} \mathrm{C}, 130 \mathrm{rpm}$ \\
\hline
\end{tabular}

\subsection{Antimicrobial Assay}

Extracts were first assayed for antimicrobial activity against the target strains using the agar disk diffusion assay method according to the EUCAST guidelines [26]. Briefly, a sterile cotton swab soaked with $0.5 \mathrm{McF}$ arland solution of each strain was spread on Petri dishes with Muller Hinton 
agar (tryptone, $17.5 \mathrm{~g} / \mathrm{L}$; beef extract, $2 \mathrm{~g} / \mathrm{L}$; soluble starch, $1.5 \mathrm{~g} / \mathrm{L}$ and Agar, $17 \mathrm{~g} / \mathrm{L}$ ). Then, cellulose disks (Oxoid) soaked with $20 \mu \mathrm{L}$ of each concentrated extract were placed on inoculated agar surface. Disks containing sterile MilliQ water and $30 \mu \mathrm{g}$ of chloramphenicol (CHF) were included as negative and positive controls. Plates were incubated at $4{ }^{\circ} \mathrm{C}$ until they were ready and transferred to $37^{\circ} \mathrm{C}$ for 16-20 h incubation. Diameters (nearest millimeter) of inhibition zones around the assayed disks were measured with a caliper from the back of plate held above a dark background. Subsequently, the extracts without antimicrobial activity were evaluated for their inhibitory effect by studying the microbial growth kinetics of the tested strains. Overnight cultures of each strain were centrifuged at $9000 \mathrm{rpm}$ for $5 \mathrm{~min}$ and the pellet was washed twice with sterile saline solution $(\mathrm{NaCl} 0.95 \%)$; after washing steps, cells were resuspended in sterile $\mathrm{NaCl}$ solution to reach the concentrations of $8 \log$ colony forming unit (cfu)/mL for Escherichia coli and Pseudomonas spp. (corresponding to the optical density, $\left.\mathrm{OD}_{600 \mathrm{~nm}}=0.3\right)$ and $7 \mathrm{log} \mathrm{cfu} / \mathrm{mL}$ for Staphylococcus spp. $\left(\mathrm{OD}_{600 \mathrm{~nm}}=0.147\right)$. Then, each culture solution was inoculated at a final concentration of ca. $3 \log \mathrm{cfu} / \mathrm{mL}$ in $96-$-well flat-bottomed microtiter plates (Corning ${ }^{\mathrm{TM}}$, Corning, NY, USA) filled with the appropriate medium (100 $\mu \mathrm{L}$; Table 1) supplemented with $20 \mu \mathrm{L}$ of MilliQ water (control), HWE or MAE extracts. Microtiter plates were incubated at the optimal growth temperature (Table 1) for $24 \mathrm{~h}$ and cell growth was determined at 10 min-time intervals by measuring OD at $600 \mathrm{~nm}$ using an automated Microplate reader (Varioskan Flash, Thermo Fisher, Milan, Italy). Maximum specific growth rate $\left(\mu A B S_{\max }\right)$, lag time $(\lambda A B S)$, and maximum absorbance $\left(A B S_{\max }\right)$ were estimated as described by Dalgaard and Koutsoumanis [27]. All tests were performed in triplicate.

\subsection{Static Biofilm Formation}

Biofilm formation was assayed in 96-well microtiter plates and quantified as described by O'Toole [10]. Briefly, control and treated samples, prepared in triplicates as described above, were incubated at 30 and $37^{\circ} \mathrm{C}$ for $48 \mathrm{~h}$. After measuring OD at $600 \mathrm{~nm}$ after 24 and $48 \mathrm{~h}$ incubation, plates were carefully removed and each well was washed twice with distilled water. The biofilm cells adhering to the bottom and side of each well were then stained with crystal violet $(\mathrm{CV} ; 0.1 \%, w / v)$. After a second washing step, biofilm-associated crystal violet was solubilized with $30 \%$ acetic acid $(v / v)$ and its optical density was measured at $570 \mathrm{~nm}$ using a Microplate reader (Varioskan Flash).

\subsection{Statistical Analysis}

A two-way analysis of variance (ANOVA) was conducted with SPSS 20.0 IMB-SPSS statistic software version 20 (IMB corp., Chicago, IL, USA) to examine the effects of citrus peel origin and extraction methods. The relationship between time and temperature levels with the growth kinetic parameters of each treated target strains were assessed for the extracts. The same analysis was performed in order to evaluate the effects on planktonic cell optical density and related biofilm biomass. Multi-comparison analyses among mean values was performed by using Fisher's least significant difference test at $95 \%$ Interval Confidence.

\section{Results and Discussion}

Citrus is an important agricultural crop mainly used in food industries for fresh juice production. The resulting peel and pomaces in citrus processing are by-products that have been used as a source of molasses, pectin, and fragrances [21], and antioxidant and antimicrobial compounds such as phenolic acids and flavonoids $[19,28,29]$. The conventional extraction of these compounds is usually performed by refluxing peels in large quantities of organic solvents such as ethanol, methanol, ethyl acetate, and acetone. Reports on the phytochemical analyses of these extracts have shown the presence of flavonoids, saponins, tannins, alkaloids, and terpenoids [13]. During the last decade, the extraction of citrus by-products from dried peels/pomace with hot water has increasingly taken hold to allow improved recovery (mostly polyphenols and phenolics) and reduce the extraction time [19,30-33]. Accordingly, we compared herein the antimicrobial and antibiofilm activity of hot water extracts obtained from three 
different citrus peels. The extractions were performed by either MAE (at two temperature settings) or the conventional extraction method (HWE). MAE methods are faster than conventional heating processes because microwave energy is delivered efficiently to materials with polar or dipole molecules (such as polyphenols, glycosides, and minerals) through molecular interaction with the electromagnetic field; they also offer a rapid transfer of energy to both solvent and raw plant materials [34]. MAE is not widely used to extract polyphenols from plant tissues in water due to its high dielectric factor and low dispersion coefficient [29,34,35]. Nevertheless, its application under these conditions could favor the extraction of flavonoid glycosides, widespread in citrus peels and previously extracted with prolonged hot infusion [30,32,36].

In the present study, the different extraction methodologies employed did not lead to significant differences in extraction yield in relation to the citrus peel origin or extraction procedures (Figure 1). These values, ranging from $18.0 \%$ to $21.5 \%$ (as dry matter), were consistent with those previously found by other authors for acetone and ethanol extracts from mandarin peels [37,38] and generally used for other citrus peels. However, concentrated extracts (corresponding to an average concentration of $157 \pm 14 \mu \mathrm{g} / \mathrm{mL}$ ) showed no inhibitory halos on disc diffusion plates, partially in accordance with data previously reported for aqueous extracts from Brazilian medicinal plants mostly containing tannins $[39,40]$. Nevertheless, the standardized inhibitory agar diffusion test relies on endpoint growth determination and it is not intended for monitoring microbial kinetics with high temporal resolution in the presence of putative antimicrobial extracts [26]. In fact, inhibitory compounds may exert specific effects on growing microorganisms by impairing cell wall synthesis or substrate uptake and interfering with nucleotides and proteins synthesis [41]. Accordingly, MAE- and HWE-extracts were evaluated for their action on growth kinetics and related primary growth model parameters of target strains in comparison with the untreated control cultures (Tables 2 and 3). A two-way ANOVA was conducted to examine the effect of three peel origins and five different peel extracts on growth kinetic parameters of several bacterial strains. There was a statistically significant interaction $(p<0.001)$ between the effects of citrus peel origin and extract types on most growth kinetic parameters. In general, simple main effects analysis showed that lemon and orange peel MAE-extracts significantly reduced growth rate and maximum growth levels, and extended lag time of most tested strains compared to the control and HWE-extracts.

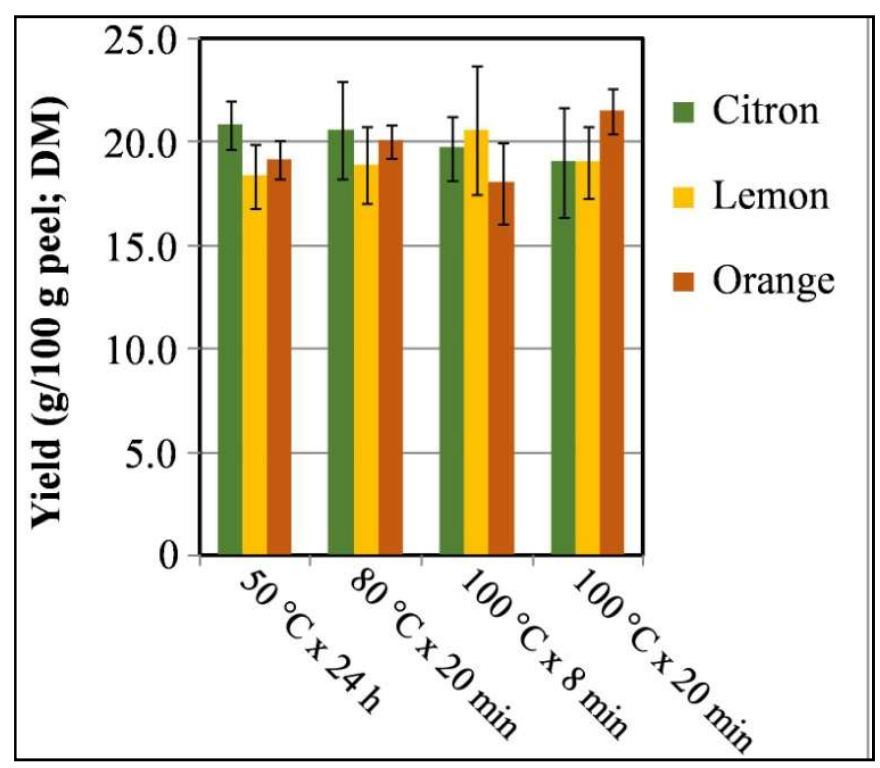

Figure 1. Mean yield percentages (as dry matter) of water extracts obtained from citron, lemon, and orange peels upon hot water extraction (HWE) $\left(50^{\circ} \mathrm{C} \times 24 \mathrm{~h}\right)$ and microwave assisted extraction (MAE) $\left(80{ }^{\circ} \mathrm{C} \times 20 \mathrm{~min}, 100^{\circ} \mathrm{C} \times 8 \mathrm{~min}, 100^{\circ} \mathrm{C} \times 20 \mathrm{~min}\right)$. Bars represent standard deviations $(n=3)$. 
For the sake of brevity, only some more significant growth kinetics have been reported for up to $21 \mathrm{~h}$ of incubation in Figure 2. Overall, despite the lush growth of untreated cultures, MAE- and HWE-extracts exerted an inhibiting action on target strains resulting in a significant $(p<0.01)$ increase of lag time $(\lambda A B S)$ and reduction of $A B S_{\max }$ (Table 2 and Figure 2). As shown in Figure 2A, citron peel MAE-extracts $\left(80^{\circ} \mathrm{C} \times 20 \mathrm{~min}\right.$ and $\left.100{ }^{\circ} \mathrm{C} \times 8 \mathrm{~min}\right)$ reduced the maximum $E$. coli $\mathrm{K} 12$ turbidity levels by an average of $0.180 \mathrm{OD}$ units compared to the remaining samples even though their lag times were similar (Table 3). All lemon peel extracts were active in efficiently controlling growth rate and the final microbial turbidity of psychrotrophic P. fluorescens ITEM 17298 (Figure 2B). While all MAE-extracts from orange peels efficiently kept $P$. fluorescens ITEM 17298 growth very low (Figure 2D), only extracts processed by MAE at $100{ }^{\circ} \mathrm{C}$ for 8 min were significantly $(p<0.001)$ effective in reducing the final optical density of $S$. caprae (Figure 2C). Hence, the optimum condition to extract growth modulators would be to lower the temperature to $80^{\circ} \mathrm{C}$ and increase extraction time to $20 \mathrm{~min}$.

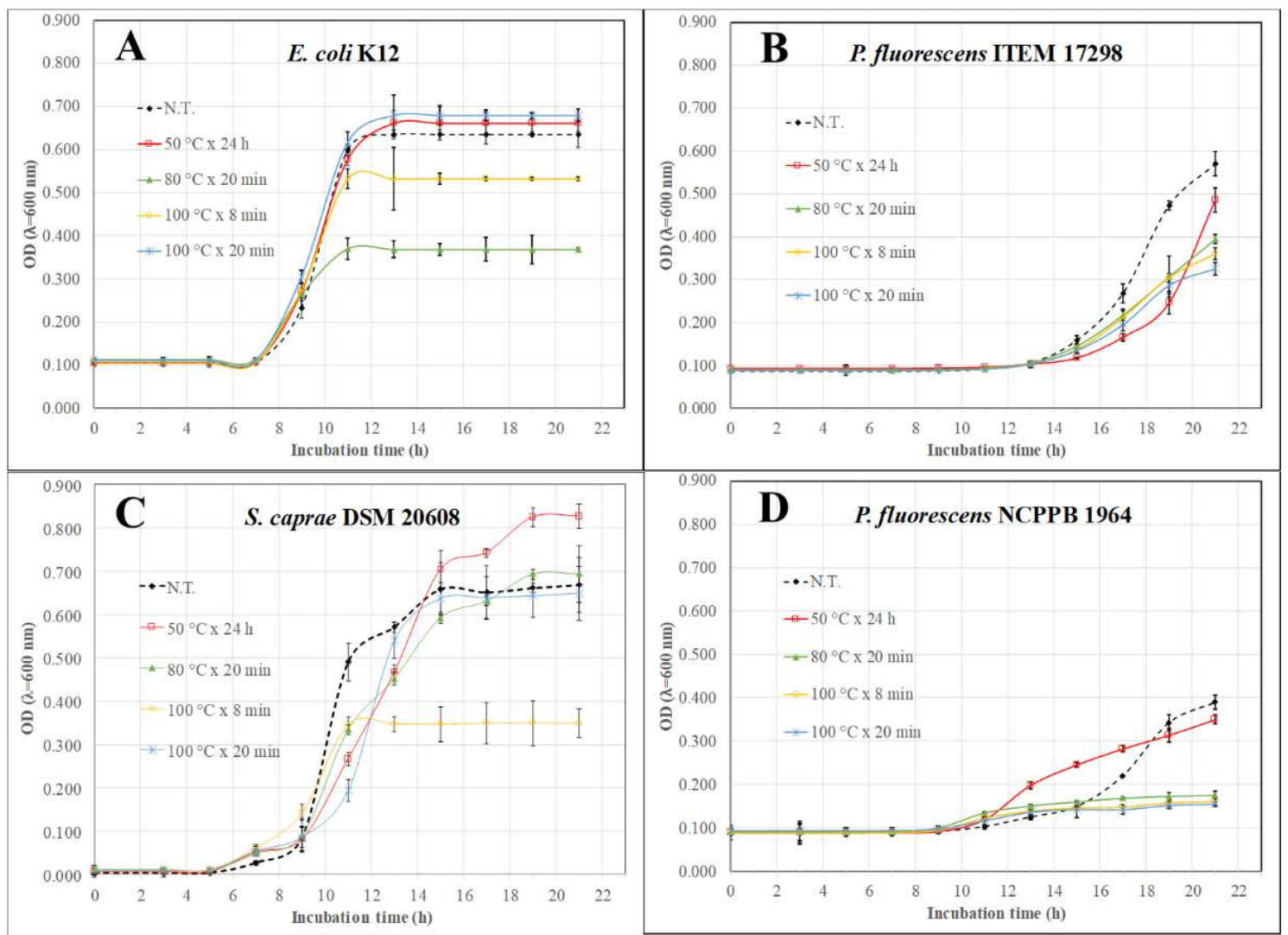

Figure 2. Growth kinetics of some tested strains amended with extracts from citron(A), lemon (B) and orange $(\mathbf{C}, \mathbf{D})$ peels by hot water extraction $\left(50^{\circ} \mathrm{C} \times 24 \mathrm{~h}\right)$ and microwave assisted extraction $\left(80^{\circ} \mathrm{C} \times\right.$ $20 \mathrm{~min}, 100{ }^{\circ} \mathrm{C} \times 8 \mathrm{~min}, 100^{\circ} \mathrm{C} \times 20 \mathrm{~min}$ ); N.T.: not treated. Bars represent standard deviation.

The primary growth model parameters are generally associated with bacterial adaptation to growth environment, antimicrobial sub-lethal concentrations, and nutrient depletion or toxic metabolite accumulation, respectively [42,43]. In our work, some target strains (P. fluorescens 84094, P. fluorescens NCPPB 1964, S. saprophyticus UR18), mostly growing in the presence of MAE extracts, showed a sharp $\lambda A B S$ increase followed by a relevant $A B S_{\max }$ decrease. Conversely, at the same conditions, other strains (P. fluorescens ITEM 17298 and ITEM 17299, P. fluorescens NCPPB 1964) recorded a marked delayed growth and higher final turbidity increases than the related untreated control cultures. This biphasic growth pattern (hormetic effect) resembled that found in bacteria treated with sub-lethal concentrations of antibiotics generally leading to selective enrichment and overgrowth of tolerant bacteria and enhancing dissemination of multidrug resistance [44]. On the other hand, 
an evident inhibitory effect was recorded for the cultures of the strains ITEM 17298, NCPPB 1964, and UR18 grown in the presence of MAE-lemon and -orange extracts that displayed a significant extension of lag time as well as a reduction of growth rate in comparison with untreated control cultures. Similar effects were also reported for registered water extracts (mostly containing flavonoid glycosides, terpenoids, and phenolic acids) from both Stevia rebaudiana and citrus extracts against Listeria innocua and different spoilage bacteria and yeasts, respectively $[45,46]$.

Table 2. Lag phase $(\lambda A B S)$ and maximum optical density $\left(A B S_{\max }\right)$ shown by bacterial cultures amended with different aqueous extracts of citron, lemon, and orange peels.

\begin{tabular}{|c|c|c|c|c|c|c|c|c|c|}
\hline \multirow{2}{*}{ Bacterial Strain } & \multirow[b]{2}{*}{ Extracts } & Citron & Lemon & Orange & LSD & Citron & Lemon & Orange & LSD \\
\hline & & \multicolumn{4}{|c|}{$\lambda A B S(\mathrm{~h})$} & \multicolumn{4}{|c|}{$A B S_{\max }$} \\
\hline \multirow{5}{*}{ E. coli $\mathrm{K} 12$} & N.T. & 7.4 & 7.3 & 6.9 & \multirow{5}{*}{ n.s. } & 0.711 & 0.699 & 0.664 & \multirow{5}{*}{0.109} \\
\hline & HWE & 9.1 & 8.6 & 7.7 & & 0.642 & 0.785 & 1.249 & \\
\hline & MAE1 & 10.1 & 10.8 & 9.5 & & 0.368 & 0.733 & 1.186 & \\
\hline & MAE2 & 9.4 & 9.7 & 8.9 & & 0.532 & 0.800 & 1.000 & \\
\hline & MAE3 & 9.1 & 11.1 & 13.8 & & 0.679 & 0.787 & 1.180 & \\
\hline \multirow{5}{*}{ P. fluorescens 84094} & N.T. & 12.3 & 12.1 & 11.5 & \multirow{5}{*}{1.9} & 0.687 & 0.676 & 0.642 & \multirow{5}{*}{0.180} \\
\hline & HWE & 13.4 & 7.9 & 13.8 & & 0.805 & 0.999 & 0.611 & \\
\hline & MAE1 & 12.0 & 7.6 & 12.1 & & 1.141 & 1.036 & 0.929 & \\
\hline & MAE2 & 13.8 & 6.8 & 12.4 & & 0.747 & 1.042 & 0.844 & \\
\hline & MAE3 & 14.2 & 8.1 & 12.2 & & 0.654 & 0.966 & 0.909 & \\
\hline \multirow{5}{*}{ P. fluorescens ITEM 17298} & N.T. & 13.5 & 13.2 & 12.6 & \multirow{5}{*}{1.5} & 0.541 & 0.532 & 0.506 & \multirow{5}{*}{0.057} \\
\hline & HWE & 13.8 & 13.0 & 10.8 & & 0.678 & 0.475 & 0.549 & \\
\hline & MAE1 & 15.5 & 14.3 & 10.8 & & 0.900 & 0.298 & 0.695 & \\
\hline & MAE2 & 15.6 & 15.5 & 10.7 & & 0.735 & 0.269 & 0.559 & \\
\hline & MAE3 & 14.9 & 14.7 & 10.7 & & 0.800 & 0.291 & 0.523 & \\
\hline \multirow{5}{*}{ P. fluorescens ITEM 17299} & N.T. & 13.1 & 12.8 & 12.2 & \multirow{5}{*}{1.6} & 0.549 & 0.540 & 0.513 & \multirow{5}{*}{$0.18 \mathrm{~s}$} \\
\hline & HWE & 14.8 & 14.0 & 9.7 & & 1.091 & 1.174 & 0.772 & \\
\hline & MAE1 & 14.3 & 14.7 & 9.8 & & 1.010 & 0.897 & 0.557 & \\
\hline & MAE2 & 14.3 & 13.7 & 11.1 & & 0.956 & 0.982 & 0.619 & \\
\hline & MAE3 & 15.2 & 14.2 & 11.5 & & 0.934 & 0.823 & 0.524 & \\
\hline \multirow{5}{*}{ P. fluorescens NCPPB 1964} & N.T. & 13.5 & 13.2 & 12.6 & \multirow{5}{*}{2.0} & 0.41 & 0.41 & 0.39 & \\
\hline & HWE & 20.0 & 14.0 & 10.3 & & 0.304 & 0.516 & 0.350 & \\
\hline & MAE1 & 20.0 & 15.2 & 21.6 & & 0.293 & 0.430 & 0.176 & 0.034 \\
\hline & MAE2 & 19.4 & 14.9 & 25.5 & & 0.304 & 0.427 & 0.161 & \\
\hline & MAE3 & 16.9 & 15.0 & 31.5 & & 0.475 & 0.420 & 0.155 & \\
\hline & N.T. & 14.9 & 14.6 & 14.1 & & 0.399 & 0.392 & 0.372 & \\
\hline & HWE & 16.3 & 9.8 & 11.9 & & 0.846 & 0.994 & 1.528 & \\
\hline P. putida ITEM 17297 & MAE1 & 16.5 & 9.2 & 13.9 & 3.2 & 1.592 & 0.780 & 1.414 & 0.576 \\
\hline & MAE2 & 16.4 & 7.8 & 13.6 & & 1.569 & 0.877 & 1.426 & \\
\hline & MAE3 & 16.5 & 5.2 & 13.2 & & 1.586 & 0.930 & 1.402 & \\
\hline & N.T. & 14.0 & 13.8 & 13.1 & & 0.713 & 0.700 & 0.666 & \\
\hline & HWE & 13.6 & 7.3 & 2.4 & & 1.198 & 1.293 & 0.824 & \\
\hline S. caprae DSM 20608 & MAE1 & 13.3 & 4.9 & 8.1 & 1.6 & 1.108 & 1.153 & 0.693 & 0.210 \\
\hline & MAE2 & 13.1 & 5.1 & 9.3 & & 1.163 & 1.229 & 0.349 & \\
\hline & MAE3 & 13.1 & 5.7 & 8.6 & & 1.255 & 1.206 & 0.648 & \\
\hline & N.T. & 9.3 & - & - & & 0.902 & - & - & \\
\hline & HWE & 8.3 & - & - & & 1.224 & - & - & \\
\hline S. epidermidis UR63 & MAE1 & 7.0 & - & - & 1.0 & 1.248 & - & - & 0.125 \\
\hline & MAE2 & 6.6 & - & - & & 1.253 & - & - & \\
\hline & MAE3 & 7.8 & - & - & & 1.217 & - & - & \\
\hline & N.T. & - & 7.0 & 6.9 & & - & 0.354 & 0.348 & \\
\hline & HWE & - & 11.1 & 9.5 & & - & 0.362 & 0.342 & \\
\hline S. saprophyticus UR18 & MAE1 & - & 9.3 & 10.8 & 1.3 & - & 0.406 & 0.400 & 0.038 \\
\hline & MAE2 & - & 10.9 & 10.5 & & - & 0.426 & 0.318 & \\
\hline & MAE3 & - & 9.8 & 14.2 & & - & 0.420 & 0.414 & \\
\hline & N.T. & 11.3 & 11.1 & - & & 0.901 & 0.885 & - & \\
\hline & HWE & 13.4 & 3.9 & - & & 1.079 & 1.063 & - & \\
\hline S. xylosus DSM20266T & MAE1 & 12.2 & 8.8 & - & 1.2 & 1.108 & 1.041 & - & 0.088 \\
\hline & MAE2 & 12.2 & 9.0 & - & & 1.199 & 0.430 & - & \\
\hline & MAE3 & 12.2 & 8.0 & - & & 1.231 & 0.807 & - & \\
\hline
\end{tabular}

N.T.: Not treated; HWE: Extract obtained at $50^{\circ} \mathrm{C} \times 24 \mathrm{~h}$; MAE1: Extract obtained at $80^{\circ} \mathrm{C} \times 20 \mathrm{~min}$; MAE2: Extract obtained at $100^{\circ} \mathrm{C} \times 8 \mathrm{~min}$; MAE3: Extract obtained at $100^{\circ} \mathrm{C} \times 20 \mathrm{~min}$. Mean values from the same strain were compared by Fisher's least significant difference (LSD) multiple-comparison test (95\% Confidence Intervals). 
Table 3. Growth rates ( $\mu A B S$ ) and duplication time (DT) shown by bacterial cultures amended with different aqueous extracts of citron, lemon, and orange peels.

\begin{tabular}{|c|c|c|c|c|c|c|c|c|c|}
\hline \multirow{2}{*}{ Header } & \multirow[b]{2}{*}{ Extracts } & Citron & Lemon & Orange & \multirow[t]{2}{*}{ LSD } & Citron & Lemon & Orange & LSD \\
\hline & & & $A B S\left(\mathrm{~h}^{-}\right.$ & & & \multicolumn{4}{|c|}{ DT (h) } \\
\hline \multirow{5}{*}{ E. coli $\mathrm{K} 12$} & N.T. & 0.231 & 0.227 & 0.216 & \multirow{5}{*}{0.081} & 4.3 & 4.2 & 4.0 & \multirow{5}{*}{1.9} \\
\hline & HWE & 0.420 & 0.123 & 0.206 & & 1.6 & 5.8 & 3.5 & \\
\hline & MAE1 & 0.294 & 0.160 & 0.220 & & 2.3 & 4.1 & 3.3 & \\
\hline & MAE2 & 0.402 & 0.220 & 0.212 & & 1.7 & 3.5 & 3.4 & \\
\hline & MAE3 & 0.426 & 0.173 & 0.394 & & 1.6 & 3.9 & 1.8 & \\
\hline \multirow{5}{*}{ P. fluorescens 84094} & N.T. & 0.234 & 0.230 & 0.219 & \multirow{5}{*}{0.023} & 3.3 & 3.2 & 3.0 & \multirow{5}{*}{0.5} \\
\hline & HWE & 0.230 & 0.166 & 0.250 & & 2.9 & 4.3 & 2.9 & \\
\hline & MAE1 & 0.225 & 0.168 & 0.254 & & 3.0 & 4.3 & 2.8 & \\
\hline & MAE2 & 0.214 & 0.163 & 0.256 & & 3.1 & 4.1 & 2.8 & \\
\hline & MAE3 & 0.202 & 0.165 & 0.261 & & 3.3 & 4.0 & 2.7 & \\
\hline \multirow{5}{*}{ P. fluorescens ITEM 17298} & N.T. & 0.215 & 0.211 & 0.201 & \multirow{5}{*}{0.023} & 3.7 & 3.6 & 3.4 & \multirow{5}{*}{0.5} \\
\hline & HWE & 0.184 & 0.192 & 0.167 & & 3.9 & 3.5 & 4.3 & \\
\hline & MAE1 & 0.309 & 0.141 & 0.204 & & 2.3 & 4.9 & 3.5 & \\
\hline & MAE2 & 0.277 & 0.135 & 0.174 & & 2.6 & 5.0 & 4.1 & \\
\hline & MAE3 & 0.258 & 0.139 & 0.169 & & 2.8 & 5.0 & 4.2 & \\
\hline \multirow{5}{*}{ P. fluorescens ITEM 17299} & N.T. & 0.213 & 0.209 & 0.199 & \multirow{5}{*}{0.056} & 3.6 & 3.5 & 3.3 & \multirow{5}{*}{0.7} \\
\hline & HWE & 0.313 & 0.331 & 0.194 & & 2.3 & 2.2 & 3.7 & \\
\hline & MAE1 & 0.289 & 0.314 & 0.155 & & 2.5 & 2.3 & 4.6 & \\
\hline & MAE2 & 0.302 & 0.315 & 0.194 & & 2.4 & 2.1 & 3.7 & \\
\hline & MAE3 & 0.293 & 0.286 & 0.182 & & 2.4 & 2.4 & 3.9 & \\
\hline \multirow{5}{*}{ P. fluorescens NCPPB 1964} & N.T. & 0.162 & 0.159 & 0.152 & \multirow{5}{*}{0.015} & 6.5 & 3.9 & 6.3 & \\
\hline & HWE & 0.113 & 0.176 & 0.110 & & 5.6 & 4.0 & 12.3 & \\
\hline & MAE1 & 0.128 & 0.164 & 0.056 & & 7.0 & 4.2 & 14.1 & 1.1 \\
\hline & MAE2 & 0.106 & 0.161 & 0.049 & & 3.3 & 4.2 & 16.4 & \\
\hline & MAE3 & 0.215 & 0.159 & 0.042 & & 3.8 & 3.8 & 3.6 & \\
\hline & N.T. & 0.212 & 0.208 & 0.198 & & 2.0 & 3.3 & 2.1 & \\
\hline & HWE & 0.351 & 0.219 & 0.344 & & 1.4 & 4.0 & 1.6 & \\
\hline P. putida ITEM 17297 & MAE1 & 0.514 & 0.172 & 0.438 & 0.071 & 1.4 & 4.2 & 1.7 & 1.3 \\
\hline & MAE2 & 0.513 & 0.163 & 0.422 & & 1.4 & 5.2 & 1.8 & \\
\hline & MAE3 & 0.528 & 0.141 & 0.392 & & 2.1 & 2.0 & 1.9 & \\
\hline & N.T. & 0.378 & 0.372 & 0.353 & & 2.1 & 1.9 & 1.9 & \\
\hline & HWE & 0.334 & 0.375 & 0.349 & & 2.4 & 2.4 & 1.7 & \\
\hline S. caprae DSM 20608 & MAE1 & 0.305 & 0.277 & 0.399 & 0.060 & 2.3 & 2.3 & 1.9 & 0.3 \\
\hline & MAE2 & 0.306 & 0.292 & 0.359 & & 2.3 & 2.1 & 1.9 & \\
\hline & MAE3 & 0.315 & 0.315 & 0.402 & & 1.3 & - & & \\
\hline & N.T. & 0.549 & - & - & & 1.5 & - & - & \\
\hline & HWE & 0.494 & - & - & & 1.7 & - & - & \\
\hline S. epidermidis UR63 & MAE1 & 0.414 & - & - & 0.057 & 1.7 & - & - & 0.4 \\
\hline & MAE2 & 0.419 & - & - & & 2.0 & - & - & \\
\hline & MAE3 & 0.352 & - & - & & - & - & - & \\
\hline & N.T. & - & 0.155 & 0.153 & & - & 4.8 & 4.7 & \\
\hline & HWE & - & 0.169 & 0.206 & & - & 4.2 & 3.5 & \\
\hline S. saprophyticus UR18 & MAE1 & - & 0.164 & 0.220 & 0.025 & - & 4.4 & 3.3 & 0.5 \\
\hline & MAE2 & - & 0.148 & 0.212 & & - & 4.9 & 3.4 & \\
\hline & MAE3 & - & 0.163 & 0.394 & & - & 4.4 & 1.8 & \\
\hline & N.T. & 0.341 & 0.336 & - & & 2.1 & 2.0 & - & \\
\hline & HWE & 0.234 & 0.332 & - & & 3.1 & 2.0 & - & \\
\hline S. xylosus DSM20266T & MAE1 & 0.203 & 0.407 & - & 0.032 & - & 4.8 & 4.7 & 0.30 .5 \\
\hline & MAE2 & 0.220 & 0.272 & - & & - & 4.2 & 3.5 & \\
\hline & MAE3 & 0.221 & 0.274 & - & & - & 4.4 & 3.3 & \\
\hline
\end{tabular}

N.T.: Not treated; HWE: Extract obtained at $50^{\circ} \mathrm{C} \times 24 \mathrm{~h}$; MAE1: Extract obtained at $80{ }^{\circ} \mathrm{C} \times 20$ min; MAE2: Extract obtained at $100{ }^{\circ} \mathrm{C} \times 8 \mathrm{~min}$; MAE3: Extract obtained at $100{ }^{\circ} \mathrm{C} \times 20 \mathrm{~min}$. Mean values from the same strain were compared by Fisher's least significant difference (LSD) multiple-comparison test (95\% Confidence Intervals).

As widely reported, pseudomonads and staphylococci are able to form biofilm on biotic and abiotic surfaces. Biofilm phenotypes are resistant to common control strategies and consequently showed an increased persistence in the environment. In order to find novel antibiofilm agents, each extract was then assayed for their ability to counteract biofilm formation. Overall, untreated cultures produced high amounts of biofilm biomass $\left(0.4<\mathrm{OD}_{570 \mathrm{~nm}}<4\right)$, except for E. coli that produced a low amount of biofilm $\left(\mathrm{OD}_{570 \mathrm{~nm}}<0.150\right.$; Figure $\left.3 \mathrm{~F}\right)$. Two-way ANOVA analysis highlighted that 
the interaction between the experimental factors, plant origin of the peels, and the extraction method applied, significantly $(p<0.001)$ affected the biofilm biomass of all tested strains except for E. coli K12 and S. saprophyticus UR18 strains. By contrast, biofilm formation by NCPPB 1964, ITEM 17297, and DSM 20608 strains were reduced regardless of the assayed extract (Figures 3 and 4). The combined treatment (peel origin $\times$ extraction procedure) resulted in higher than $50 \%$ reduction on only five tested strains that are also considered strong biofilm producers (Figures 3 and 4). Indeed, all extracts fully counteracted ITEM 17297 biofilm formation, whereas orange peel MAE-extracts and citron peel HWE-extracts were similarly active against $P$. fluorescens ITEM 17298, S. epidermidis UR63, and S. saprophyticus UR18, respectively. Comparable biofilm reduction values were registered only in the cultures of the strains ITEM 17298, ITEM 17299, UR63, and UR18 treated with the citron peel HWE-extracts; by contrast citron extract obtained at $100{ }^{\circ} \mathrm{C}$ by MAE was highly active against ITEM 17299 and UR63 (Figures 3 and 4).

These results were partially consistent with those observed on growth patterns described in the first $21 \mathrm{~h}$ of incubation. Indeed, it is noteworthy that biofilm formation of the strain ITEM 17297 was fully inhibited by all extracts among which those from lemons affected bacterial lag phase and growth rate (Tables 2 and 3, and Figure 3). On the other hand, NCPPB 1964 displaying a significant extension of lag time as well as a reduction of growth rate in the presence of lemon and orange MAE-extracts (Tables 2 and 3, and Figure 2D) showed a scarce but significant $(p<0.05)$ inhibition of biofilm formation (25\% on average; Figure 3A). In addition, even though DSM 20608 biofilm was moderately inhibited by all extracts (by about $29 \%$ ), its growth rate and final growth level were negatively affected only by lemon peel extracts $\left(80{ }^{\circ} \mathrm{C} \times 20 \mathrm{~min}\right.$ and $\left.100{ }^{\circ} \mathrm{C} \times 8 \mathrm{~min}\right)$ and orange peel extract $\left(100^{\circ} \mathrm{C} \times 8 \mathrm{~min}\right)$, respectively (Figure $2 \mathrm{C}$ and Table 3$)$. Likewise, in the presence of citron peel HWE-extract and orange and lemon peel MAE-extracts ITEM 17298 showed a sharp reduction in growth rate compared to not treated control culture (Table 3 and Figure 2B), whereas biofilm biomass was highly lowered by all orange extracts (Figure 3C). Conversely, all lemon extracts counteracting the growth of the same strain did not show any inhibitory effect on its biofilm formation. Interestingly, citron extracts negatively affected both growth rate and biofilm formation of S. epidermidis UR63 (Table 3 and Figure 4B). Even though all tested citrus peel water extracts had no bactericidal effect against several strains, some of them (mostly MAE-extracts) can control bacterial growth parameters and negatively affect biofilm formation of the susceptible strains. Several studies have shown that plant-derived compounds and antimicrobials at sub-lethal doses impair adhesion and bacterial biofilm formation while inducing planktonic growth of a hypermotile phenotype [47-49]. This strategy can be used to disarm microorganisms of sanitary interest without killing them or opposing a selective pressure on them but reducing their virulence or increasing susceptibility [50]. Likewise, polyphenols have received some attention regarding their antimicrobial effect upon biofilms produced by S. epidermidis [31]; tannins from water-extracts of some Brazilian medicinal plants allowed a bacteriostatic behaviour of pathogen Pseudomonas aeruginosa but strongly reduced its biofilm biomass [40]. Considering coumarins, Villa and Cappitelli [51] have recently proposed them as alternative therapeutic strategies based on their ability to block the quorum sensing signalling systems and to inhibit the formation of biofilms in clinically relevant pathogens. Similar evidence was also found for flavonoids abundant in citrus peels, like naringenin against Streptococcus mutans and phenolic acids like cinnamic acid against drug multi-resistant P. aeruginosa PAO1 [52]. 

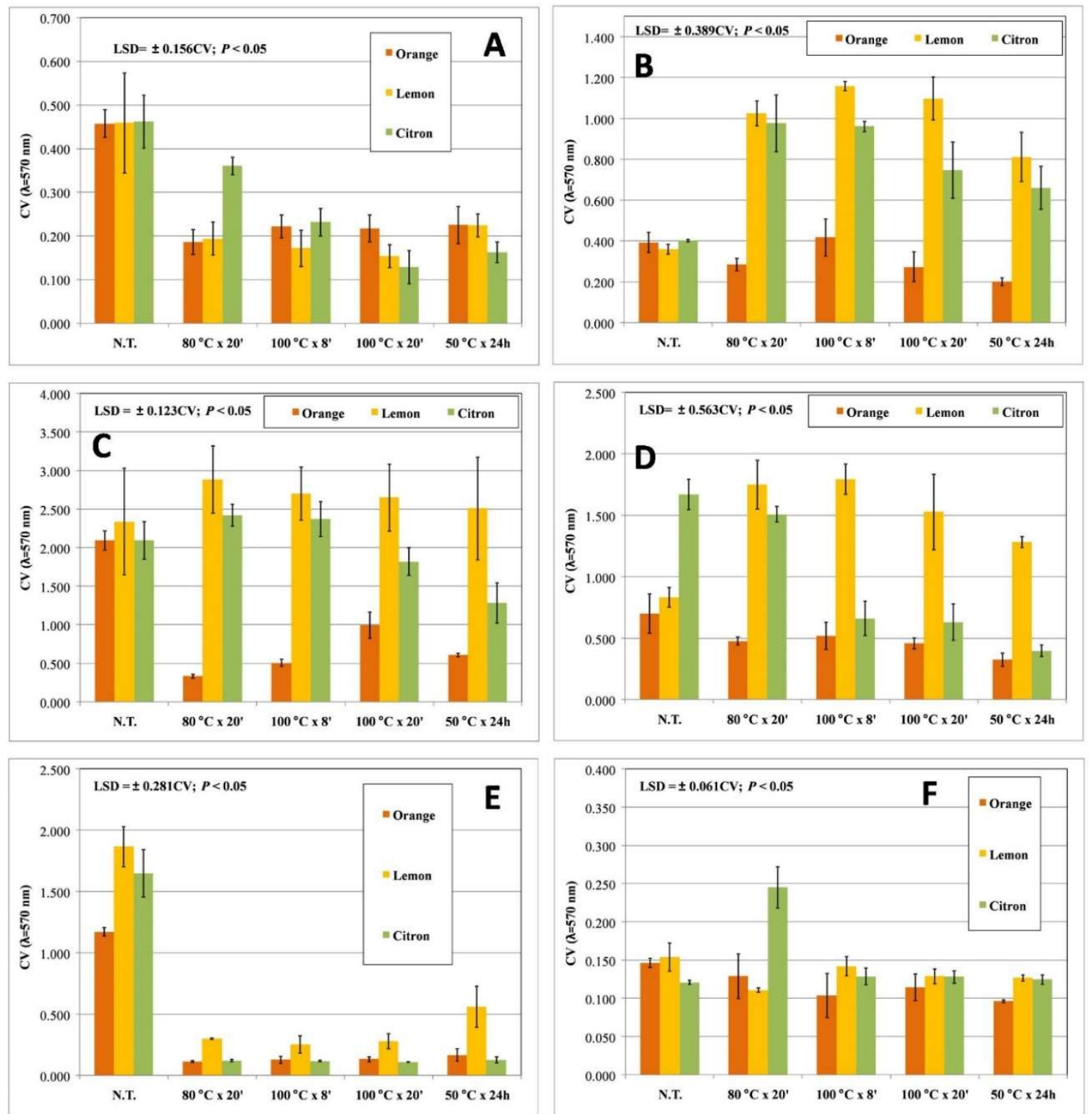

Figure 3. Biofilm biomass produced by P. fluorescens NCPPB 1964 (A), P. fluorescens 84094 (B), P. fluorescens ITEM 17298 (C), P. fluorescens ITEM 17299 (D), P. putida ITEM 17297 (E), and E. coli $\mathrm{K} 12(\mathrm{~F})$ in the presence of different citrus peel water extracts. Mean values (bars \pm standard deviation) from the same strain were compared by Fisher's least significant difference (LSD) multiple-comparison test (95\% Confidence Intervals); N.T.: not treated. 

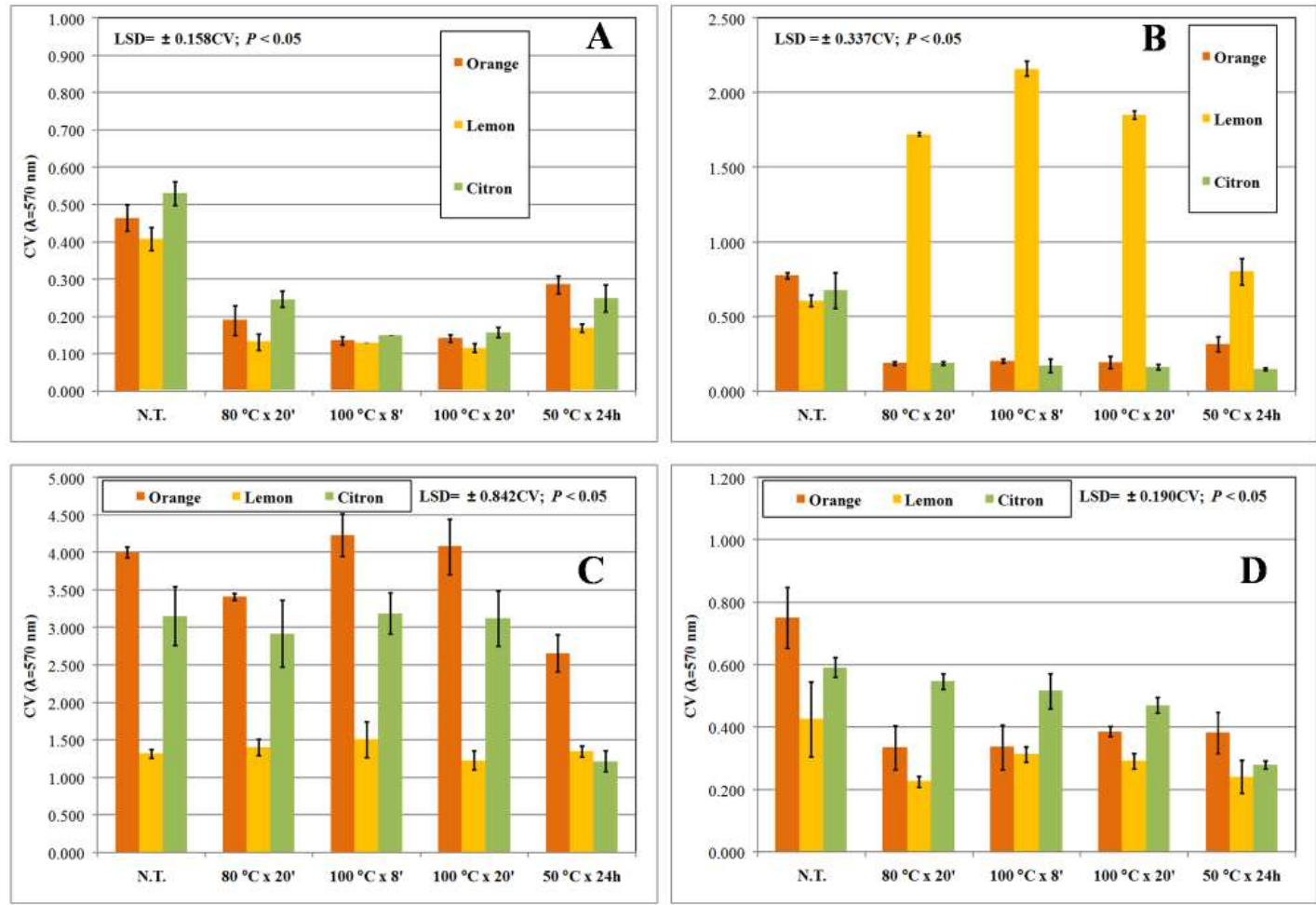

Figure 4. Biofilm biomass produced by S. caprae DSM 20608 (A), S. epidermidis UR63 (B), S. saprophyticus UR18 (C), and S. xylosus DSM 20266T (D) in the presence of different citrus peel water extracts. Mean values (bars \pm standard deviation) from the same strain were compared by Fisher's least significant difference (LSD) multiple-comparison test (95\% Confidence Intervals); N.T.: not treated.

\section{Conclusions}

In this study, aqueous extracts obtained from lemon, orange, and citron peels by either HWE or three MAE procedures were assayed for their antimicrobial and antibiofilm activities against several human skin commensal bacteria and opportunistic pathogens correlated with nosocomial infections. Even though bactericidal effects were not observed, citrus water extracts showed inhibitory activity by negatively affecting lag time, growth rate, and final growth level of most target strains. Compared to conventional HWE, the application of MAE performed at $100{ }^{\circ} \mathrm{C}$ significantly affect the number of strains susceptible mostly to orange and lemon citrus peel extracts by significantly reducing growth rate and lag phase. Nevertheless, only some treated susceptible strains (i.e., ITEM 17297 and UR63) formed significantly lesser biofilm amounts than those found in untreated control cultures. Importantly, very high reductions in biofilm biomass were registered in bacterial cultures with at least one growth parameter impaired by the citrus peel extracts. These results, beyond suggesting a possible methodology to screen high numbers of extracts using turbidimetry data, pave the way for a sustainable usage of citrus peel extracts to hinder bacterial biofilm formation.

Author Contributions: Conceptualization, L.C., G.L., and L.Q.; Methodology, L.C., L.Q., and M.M.C.; Validation, L.C., L.Q., and M.M.C.; Formal Analysis, L.C.; Investigation, L.C., L.Q., and M.M.C.; Resources, L.C.; Data Curation, L.C., L.Q.; Writing-Original Draft Preparation, L.C., L.Q., and M.M.C.; Writing-Review \& Editing, S.H. and L.G.; Visualization, S.H.; Supervision, S.H. and G.L.; Project Administration, L.C., G.L.; Funding Acquisition, G.L.

Funding: This research received no external funding.

Acknowledgments: The authors are grateful to Angelo Adduci, "Consorzio del Cedro di Calabria" Association, Italy, for supplying the citron fruits. Authors thanks Michela Rizzi for her technical assistance in experimental activities.

Conflicts of Interest: The Authors declare no competing interests. 


$\begin{array}{ll}\text { Abbreviations } & \\ A B S_{\max } & \text { Maximum absorbance } \\ \text { DT } & \text { Duplication time } \\ \text { HWE } & \text { Hot water extraction } \\ \lambda A B S & \text { Lag time } \\ \text { LSD } & \text { Least significant difference } \\ \text { HWE } & \text { Hot water extraction } \\ \text { MAE } & \text { Microwave-assisted extraction } \\ \mu A B S_{\max } & \text { Maximum specific growth rate } \\ \text { N.T. } & \text { Not treated } \\ \text { CFH } & \text { Chloramphenicol }\end{array}$

\section{References}

1. Byrd, A.L.; Belkaid, Y.; Segre, J.A. The human skin microbiome. Nat. Rev. Microbiol. 2018, 16, $143-155$. [CrossRef] [PubMed]

2. Gilbert, J.A.; Blaser, M.J.; Caporaso, J.G.; Jansson, J.K.; Lynch, S.V.; Knight, R. Current understanding of the human microbiome. Nat. Med. 2018, 24, 392-400. [CrossRef] [PubMed]

3. Anderson, D.J.; Podgorny, K.; Berríos-Torres, S.I.; Bratzler, D.W.; Dellinger, E.P.; Greene, L.; Nyquist, A.-C.; Saiman, L.; Yokoe, D.S.; Maragakis, L.L.; et al. Strategies to prevent surgical site infections in acute care hospitals: 2014 update. Infect. Control Hosp. Epidemiol. 2014, 35, 605-627. [CrossRef] [PubMed]

4. Dyar, O.J.; Pagani, L.; Pulcini, C. Strategies and challenges of antimicrobial stewardship in long-term care facilities. Clin. Microbiol. Infect. 2015, 21, 10-19. [CrossRef] [PubMed]

5. Kanamori, H.; Weber, D.J.; Rutala, W.A. Healthcare outbreaks associated with a water reservoir and infection prevention strategies. Clin. Infect. Dis. 2016, 62, 1423-1435. [CrossRef] [PubMed]

6. Fontana, C.; Favaro, M. Coagulase-positive and coagulase-negative staphylococci in human disease. In Pet-to-Man Travelling Staphylococci; Savino, V., Ed.; Academic Press: London, UK, 2018; pp. $25-42$.

7. Musthaq, S.; Mazuy, A.; Jakus, J. The microbiome in dermatology. Clin. Dermatol. 2018. [CrossRef]

8. Flores-Mireles, A.L.; Walker, J.N.; Caparon, M.; Hultgren, S.J. Urinary tract infections: Epidemiology, mechanisms of infection and treatment options. Nat. Rev. Microbiol. 2015, 13, 269-284. [CrossRef] [PubMed]

9. Nishimura, T.; Hattori, K.; Inoue, A.; Ishii, T.; Yumoto, T.; Tsukahara, K.; Nakao, A.; Ishihara, S.; Nakayama, S. Bacteremia or pseudobacteremia? Review of Pseudomonas fluorescens infections. World J. Emerg. Med. 2017, 8 , 151-154. [CrossRef] [PubMed]

10. O'Toole, G.; Kaplan, H.B.; Kolter, R. Biofilm formation as microbial development. Annu. Rev. Microbiol. 2000, 54, 49-79. [CrossRef] [PubMed]

11. Parsek, M.R.; Singh, P.K. Bacterial biofilms: An emerging link to disease pathogenesis. Annu. Rev. Microbiol. 2003, 57, 677-701. [CrossRef] [PubMed]

12. Hall, C.W.; Mah, T.F. Molecular mechanisms of biofilm-based antibiotic resistance and tolerance in pathogenic bacteria. FEMS Microbiol. Rev. 2017, 41, 276-301. [CrossRef] [PubMed]

13. Negi, S. Exploring plant and agro-industrial wastes for antimicrobial biochemicals. In Biotransformation of Waste Biomass into High Value Biochemicals; Brar, S., Dhillon, G., Soccol, C., Eds.; Springer: New York, NY, USA, 2014; pp. 335-365.

14. Lanuzza, F.; Mondello, F.; Tripodo, M.M. Studies about the Utilization of Citrus Wastes in View of Environment Protection. In Pathways to Environmental Sustainability; Salomone, R., Saija, G., Eds.; Springer: London, UK, 2014; pp. 147-156.

15. Chhikara, N.; Kour, R.; Jaglan, S.; Gupta, P.; Gat, Y.; Panghal, A. Citrus medica: Nutritional, phytochemical composition and health benefits-A review. Food Funct. 2018, 9, 1978-1992. [CrossRef] [PubMed]

16. Braidy, N.; Behzad, S.; Habtemariam, S.; Ahmed, T.; Daglia, M.; Nabavi, S.M.; Sobarzo-Sanchez, E.; Nabavi, S.F. Neuroprotective effects of citrus fruit-derived flavonoids, nobiletin and tangeretin in Alzheimer's and Parkinson's disease. CNS Neurol. Disord. Drug Targets 2017, 16, 387-397. [CrossRef] [PubMed]

17. Gualdani, R.; Cavalluzzi, M.M.; Lentini, G.; Habtemariam, S. The chemistry and pharmacology of citrus limonoids. Molecules 2016, 21, 1530. [CrossRef] [PubMed] 
18. Al-Snafi, A.E. Medicinal plants with antimicrobial activities (part 2): Plant based review. Sch. Acad. J. Pharm. 2016, 5, 208-239. [CrossRef]

19. Putnik, P.; BursaćKovačević, D.; RežekJambrak, A.; Barba, F.J.; Cravotto, G.; Binello, A.; Shpigelman, A. Innovative "green" and novel strategies for the extraction of bioactive added value compounds from citrus wastes-A review. Molecules 2017, 22, 680. [CrossRef] [PubMed]

20. Flórez, N.; Conde, E.; Domínguez, H. Microwave assisted water extraction of plant compounds. J. Chem. Technol. Biotechnol. 2015, 90, 590-607. [CrossRef]

21. Shan, Y. Comprehensive Utilization of Citrus by-Products; Academic Press: London, UK, 2016; pp. $335-365$.

22. Louche, L.M.M.; Gaydou, E.M.; Lesage, J.C. Determination of phlorin as peel marker in orange (Citrus sinensis) fruits and juices. J. Agric. Food Chem. 1998, 46, 4193-4197. [CrossRef]

23. Miyake, Y.; Hiramitsu, M. Isolation and extraction of antimicrobial substances against oral bacteria from lemon peel. J. Food Sci. Technol. 2011, 48, 635-639. [CrossRef] [PubMed]

24. Adukwu, E.C.; Allen, S.C.H.; Phillips, C.A. The anti-biofilm activity of lemongrass (Cymbopogon flexuosus) and grapefruit (Citrus paradisi) essential oils against five strains of Staphylococcus aureus. J. Appl. Microbiol. 2012, 113, 1217-1227. [CrossRef] [PubMed]

25. Vikram, A.; Jayaprakasha, G.K.; Jesudhasan, P.R.; Pillai, S.D.; Patil, B.S. Suppression of bacterial cell-cell signalling, biofilm formation and type III secretion system by citrus flavonoids. J. Appl. Microbiol. 2010, 109, 515-527. [CrossRef] [PubMed]

26. EUCAST, Disk Diffusion Method for Antimicrobial Susceptibility Testing-Version 6.0, 2017. Available online: www.eucast.org (accessed on 16 May 2018).

27. Dalgaard, P.; Koutsoumanis, K. Comparison of maximum specific growth rates and lag times estimated from absorbance and viable count data by different mathematical models. J. Microbiol. Methods 2001, 43, 183-196. [CrossRef]

28. Wang, L.; Jo, M.J.; Katagiri, R.; Harata, K.; Ohta, M.; Ogawa, A.; Kamegai, M.; Ishida, Y.; Tanoue, S.; Kimura, S.; et al. Antioxidant effects of citrus pomace extracts processed by super-heated steam. LWT 2018, 90, 331-338. [CrossRef]

29. Hayat, K.; Zhang, X.; Farooq, U.; Abbas, S.; Xia, S.; Jia, C.; Zhong, F.; Zhang, J. Effect of microwave treatment on phenolic content and antioxidant activity of citrus mandarin pomace. Food Chem. 2010, 123, 423-429. [CrossRef]

30. Xu, G.H.; Chen, J.C.; Liu, D.H.; Zhang, Y.H.; Jiang, P.; Ye, X.Q. Minerals, phenolic compounds, and antioxidant capacity of citrus peel extract by hot water. J. Food Sci. 2008, 73, C11-C18. [CrossRef] [PubMed]

31. Ferrazzano, G.F.; Roberto, L.; Amato, I.; Cantile, T.; Sangianantoni, G.; Ingenito, A. Antimicrobial properties of green tea extract against cariogenic microflora: An in vivo study. J. Med. Food 2011, 14, 907-911. [CrossRef] [PubMed]

32. Di Donna, L.; Gallucci, G.; Malaj, N.; Romano, E.; Tagarelli, A.; Sindona, G. Recycling of industrial essential oil waste: Brutieridin and Melitidin, two anticholesterolaemic active principles from bergamot albedo. Food Chem. 2011, 125, 438-441. [CrossRef]

33. Papoutsis, K.; Vuong, Q.V.; Golding, J.B.; Hasperué, J.H.; Pristijono, P.; Bowyer, M.C.; Scarlett, C.J.; Stathopoulos, C.E. Pretreatment of citrus by-products affects polyphenol recovery: A review. Food Rev. Int. 2018, 1-26. [CrossRef]

34. Proestos, C.; Komaitis, N. Application of microwave-assisted extraction to the fast extraction of plant phenolic compounds. LWT 2008, 41, 652-659. [CrossRef]

35. Rahmanian, N.; Jafari, S.M.; Wani, T.A. Bioactive profile, dehydration, extraction and application of the bioactive components of olive leaves. Trends Food Sci. Tech. 2015, 42, 150-172. [CrossRef]

36. Louche, L.M.M.; Luro, F.; Gaydou, E.M.; Lesage, J.C. Phlorin screening in various citrus species and varieties. J. Agric. Food Chem. 2000, 48, 4728-4733. [CrossRef]

37. Nipornram, S.; Tochampa, W.; Rattanatraiwong, P.; Singanusong, R. Optimization of low power ultrasound-assisted extraction of phenolic compounds from mandarin (Citrus reticulata Blanco cv. Sainampueng) peel. Food Chem. 2018, 241, 338-345. [CrossRef] [PubMed]

38. Safdar, M.N.; Kausar, T.; Jabbar, S.; Mumtaz, A.; Ahad, K.; Saddozai, A.A. Extraction and quantification of polyphenols from kinnow (Citrus reticulate L.) peel using ultrasound and maceration techniques. J. Food Drug Anal. 2017, 25, 488-500. [CrossRef] [PubMed] 
39. Trentin, D.S.; Giordani, R.B.; Zimmer, K.R.; da Silva, A.G.; da Silva, M.V.; dos Santos Correia, M.T.; Baumvol, I.J.R.; Macedo, A.J. Potential of medicinal plants from the Brazilian semi-arid region (Caatinga) against Staphylococcus epidermidis planktonic and biofilm lifestyles. J. Ethnopharmacol. 2011, 137, 327-335. [CrossRef] [PubMed]

40. Trentin, D.S.; Silva, D.B.; Amaral, M.W.; Zimmer, K.R.; Silva, M.V.; Lopes, N.P.; Giordani, R.B.; Macedo, A.J. Tannins possessing bacteriostatic effect impair Pseudomonas aeruginosa adhesion and biofilm formation. PLoS ONE 2013, 8, e66257. [CrossRef] [PubMed]

41. Kohanski, M.A.; Dwyer, D.J.; Collins, J.J. How antibiotics kill bacteria: From targets to networks. Nat. Rev. Microbiol. 2010, 8, 423-435. [CrossRef] [PubMed]

42. Li, B.; Qiu, Y.; Shi, H.; Yin, H. The importance of lag time extension in determining bacterial resistance to antibiotics. Analyst 2016, 141, 3059-3067. [CrossRef] [PubMed]

43. Li, J.; Xie, S.; Ahmed, S.; Wang, F.; Gu, Y.; Zhang, C.; Chai, X.; Wu, Y.; Cai, J.; Cheng, G. Antimicrobial Activity and Resistance: Influencing Factors. Front. Pharmacol. 2017, 8, 364. [CrossRef] [PubMed]

44. Theophel, K.; Schacht, V.J.; Schlüter, M.; Schnell, S.; Stingu, C.S.; Schaumann, R.; Bunge, M. The importance of growth kinetic analysis in determining bacterial susceptibility against antibiotics and silver nanoparticles. Front. Microbiol. 2014, 5, 544. [CrossRef] [PubMed]

45. Belda-Galbis, C.M.; Pina-Pérez, M.C.; Espinosa, J.; Marco-Celdrán, A.; Martínez, A.; Rodrigo, D. Use of the modified Gompertz equation to assess the Stevia rebaudiana Bertoni antilisterial kinetics. Food Microbial. 2014, 38, 56-61. [CrossRef] [PubMed]

46. Bevilacqua, A.; Corbo, M.R.; Sinigaglia, M. In vitro evaluation of the antimicrobial activity of eugenol, limonene, and citrus extract against bacteria and yeasts, representative of the spoiling microflora of fruit juices. J. Food Prot. 2010, 73, 888-894. [CrossRef] [PubMed]

47. Deepika, M.S.; Thangam, R.; Sakthidhasan, P.; Arun, S.; Sivasubramanian, S.; Thirumurugan, R. Combined effect of a natural flavonoid rutin from Citrus sinensis and conventional antibiotic gentamicin on Pseudomonas aeruginosa biofilm formation. Food Control 2018, 90, 282-294. [CrossRef]

48. Alav, I.; Sutton, J.M.; Rahman, K.M. Role of bacterial efflux pumps in biofilm formation. J. Antimicrob. Chemother. 2018, dky042. [CrossRef] [PubMed]

49. Rasko, D.A.; Sperandio, V. Anti-virulence strategies to combat bacteria-mediated disease. Nat. Rev. Drug Discov. 2010, 9, 117-128. [CrossRef] [PubMed]

50. Reen, F.J.; Gutiérrez-Barranquero, J.A.; Parages, M.L. Coumarin: A novel player in microbial quorum sensing and biofilm formation inhibition. Appl. Microbiol. Biot. 2018, 102, 2063-2073. [CrossRef] [PubMed]

51. Villa, F.; Cappitelli, F. Plant-derived bioactive compounds at sub-lethal concentrations: Towards smart biocide-free antibiofilm strategies. Phytochem. Rev. 2013, 12, 245-254. [CrossRef]

52. Yue, J.; Yang, H.; Liu, S.; Song, F.; Guo, J.; Huang, C. Influence of naringenin on the biofilm formation of Streptococcus mutans. J. Dent. 2018. [CrossRef] [PubMed] 